\title{
Structural elucidation, molecular docking, a-amylase and a-glucosidase inhibition studies of 5-amino-nicotinic acid derivatives
}

\author{
Muhammad Nawaz ${ }^{1 *}$, Muhammad Taha ${ }^{2}$, Faiza Qureshi ${ }^{1,3}$, Nisar Ullah $^{4}$, Manikandan Selvaraj ${ }^{5}$, \\ Sumaira Shahzad ${ }^{6}$, Sridevi Chigurupati ${ }^{7}$, Abdul Waheed ${ }^{4}$ and Fadiah Ammar Almutairi ${ }^{7}$
}

\begin{abstract}
In this study, 5-amino-nicotinic acid derivatives (1-13) have been designed and synthesized to evaluate their inhibitory potential against a-amylase and a-glucosidase enzymes. The synthesized compounds (1-13) exhibited promising a-amylase and a-glucosidase activities. $I C_{50}$ values for a-amylase activity ranged between $12.17 \pm 0.14$ to $37.33 \pm 0.02 \mu \mathrm{g} / \mathrm{mL} \pm$ SEM while for a-glucosidase activity the $\mathrm{IC}_{50}$ values were ranged between $12.01 \pm 0.09$ to $38.01 \pm 0.12 \mu \mathrm{g} / \mathrm{mL} \pm$ SEM. In particular, compounds $\mathbf{2}$ and $\mathbf{4}-\mathbf{8}$ demonstrated significant inhibitory activities against a-amylase and a-glucosidase and the inhibitory potential of these compounds was comparable to the standard acarbose (10.98 \pm 0.03 and $10.79 \pm 0.17 \mu \mathrm{g} / \mathrm{mL} \pm$ SEM, respectively). In addition, the impact of substituent on the inhibitory potential of these compounds was assessed to establish structure activity relationships. Studies in molecular simulations were conducted to better comprehend the binding properties of the compounds. All the synthesized compounds were extensively characterized with modern spectroscopic methods including ${ }^{1} \mathrm{H}-\mathrm{NMR},{ }^{13} \mathrm{C}-\mathrm{NMR}, \mathrm{FTIR}$, HR-MS and elemental analysis.
\end{abstract}

Keywords: 5-Amino-nicotinic acid, Spectral studies, NMR, HR-MS, FTIR, a-Amylase activity, a-Glucosidase activity, Molecular docking

\section{Introduction}

Diabetes, a metabolic disorder with colossal consequences is always at the forefront of medical discovery. The stats are rising alarmingly, and diabetes has become one of the top risk factors leading to death [1]. A weak or poor treatment regimen leads to associated complications such as stroke, heart arrest, organ failure, limb amputation, loss of vision and damage to nervous system, as well as increased risk of fetal death during poorly controlled gestational diabetes.

*Correspondence: mnnmuhammad@iau.edu.sa

${ }^{1}$ Department of Nano-Medicine Research, Institute for Research and Medical Consultations (IRMC), Imam Abdulrahman Bin Faisal University, P.O. Box 1982, Dammam 31441, Saudi Arabia

Full list of author information is available at the end of the article
A simple delaying of the glucose absorption after food intake can play a key role towards the lifestyle and economic advantage of diabetic patients and their families, making Type II diabetes, unlike type I, considerably more curable and preventable. Therefore, an individualized treatment plan should be in place that suits the patients' need better, with respect to age, and the presence of intrinsic and acquired resistance. Scientists have been researching for hypoglycemic agents with differing mechanisms. In order to cut the chase, the ideal hypoglycemic agent is considered the one which can address the issue of imbalance between blood sugar uptake and insulin secretion in the postprandial stage where two major saccharide hydrolyzing enzymes, $\alpha$-amylase and $\alpha$-glucosidase are the optimum targets for antidiabetic treatment [2]. Presently the dominant course of diabetes

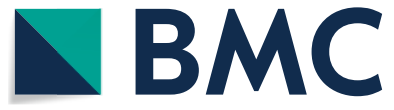

(c) The Author(s) 2020. This article is licensed under a Creative Commons Attribution 4.0 International License, which permits use, sharing, adaptation, distribution and reproduction in any medium or format, as long as you give appropriate credit to the original author(s) and the source, provide a link to the Creative Commons licence, and indicate if changes were made. The images or other third party material in this article are included in the article's Creative Commons licence, unless indicated otherwise in a credit line to the material. If material is not included in the article's Creative Commons licence and your intended use is not permitted by statutory regulation or exceeds the permitted use, you will need to obtain permission directly from the copyright holder. To view a copy of this licence, visit http://creativecommons.org/licenses/by/4.0/. The Creative Commons Public Domain Dedication waiver (http://creativecommons.org/publicdomain/zero/1.0/) applies to the data made available in this article, unless otherwise stated in a credit line to the data. 
treatment involves insulin secretagogues and sensitizers, nevertheless, the uprising of disaccharide digesting enzyme inhibitors may be the future of controlling postprandial hyperglycemia [3].

As of yet, strong $\alpha$-glucosidase inhibitors namely acarbose, miglitol, and voglibose are known for the control of postprandial hyperglycemia, but none of the above have competitive inhibiting potential against $\alpha$-amylase. An ideal candidate that can competitively inhibit both $\alpha$-amylase and $\alpha$-glucosidase can synergistically reduce and control type II diabetes [4], resulting in improved lifestyle and increased life expectancy. Majority of the marketed disaccharide digesting enzyme inhibitors are of microbial origin but associated with side-effects $[5,6]$.

Diabetes also induces or increases the risk of many associated diseases [7] such as cardiovascular diseases and hypertension, and thus ideally requires use of multidrug therapeutic regimen for the concurrent diseases. The concomitant therapy in turn leads to complications and adverse effects [8-10]. The pancreatic inhibition of $\alpha$-amylase and the action of $\alpha$-glucosidase inhibitor in intestinal region can provide an additive effect in combating diabetes [11].

This research work is designed to identifying a new class of $\alpha$-amylase inhibitors and $\alpha$-glucosidase inhibitors that can not only control prevailing diabetes but also be of therapeutic significance in prediabetes stage of insulin resistance, where the onset of the diseases can either be entirely prevented or considerably delayed $[12,13]$. It is well known that in clinical endocrinology, antidiabetics are preferably prescribed in combination with other therapeutic agents to control/suppress associated conditions. Considering the complications involved in achieving an effective combination of therapeutic agents, particularly for long-term use, it is ideal that broad spectrum carbohydrate digesting enzyme inhibitors are researched for optimum futuristic therapy for concurrent diseases.

For the most safe and versatile therapeutic solutions, we diverged into the plethora of naturally occurring medicinal compounds, specifically, nitrogen containing heterocyclic rings. Piperidine, pyridine and pyrimidine derivatives have been known to inhibit carbohydrate digesting enzymes, in addition to their anti-inflammatory, antibacterial and anticancer potencies [13-20].
In this study, derivatives of 5-amino-nicotinic acid are prepared, characterized and tested for $\alpha$-amylase and $\alpha$-glucosidase inhibiting potential.

\section{Results and discussion Chemistry}

Compounds (1-13) were prepared using 5-amino-nicotinic acid and phenyl isothiocyanates as depicted in the scheme 1. The structural confirmation of synthesized compounds (Scheme 1, Table 1) was achieved by ${ }^{1} \mathrm{H}$ NMR, ${ }^{13} \mathrm{C}-\mathrm{NMR}$, HR-MS, elemental analysis and FTIR. All synthesized compounds structures are explored by identifying their respected chemical shift in proton and carbon NMR kindly see the experiment section for details.

\section{Antidiabetic studies}

\section{a-Amylase inhibitory activity}

$\alpha$-Amylase inhibitory potential of the compounds (1-13) was tested and results are summarized in Table 1. It was observed that synthesized compounds exhibited diverse $\alpha$-amylase inhibitory activity. $\mathrm{IC}_{50}$ values for the compounds (1-13) ranged $12.17 \pm 0.14$ to $37.33 \pm 0.02 \mu \mathrm{g} /$ $\mathrm{mL} \pm$ SEM. Compounds 2, 4, 5, 6, 7 and 8 (with $\mathrm{IC}_{50}$ values $12.91 \pm 0.04,12.17 \pm 0.14,13.57 \pm 0.17,13.01 \pm 0.07$, $12.91 \pm 0.08$ and $13.04 \pm 0.02 \mu \mathrm{g} / \mathrm{mL} \pm$ SEM, respectively) exhibited good activities for $\alpha$-amylase inhibition and results were comparable with standard acarbose $(10.98 \pm 0.03 \mu \mathrm{g} / \mathrm{mL} \pm \mathrm{SEM})$. Structure activity relationship of the compounds (1-13) is also discussed. The compound 4 was observed more potent with $\mathrm{IC}_{50}$ value $12.17 \pm 0.14 \mu \mathrm{g} / \mathrm{mL} \pm \mathrm{SEM}$, followed by compound 2 $(12.91 \pm 0.04 \mu \mathrm{g} / \mathrm{mL} \pm \mathrm{SEM})$, and $7(12.91 \pm 0.08 \mu \mathrm{g} /$ $\mathrm{mL} \pm \mathrm{SEM})$. These results indicate that presence of halogens $(\mathrm{F}, \mathrm{Cl}$ and $\mathrm{Br})$ at the ring's para position is more ideal for potential $\alpha$-amylase inhibition as compare with other substituents. The compounds having methoxy (Compound 6), trifluoro (compound 8) and nitro group (compound 5) also exhibited good $\alpha$-amylase inhibition with $\mathrm{IC}_{50}$ value $13.01 \pm 0.07,13.04 \pm 0.02$ and $13.57 \pm 0.17 \mu \mathrm{g} /$ $\mathrm{mL} \pm \mathrm{SEM}$, respectively. However, unsubstituted, di-substituted and ortho/meta substituents compounds didn't show impressive $\alpha$-amylase inhibition activity $(\mathbf{1}, \mathbf{3}$ and 9-13 compounds) (Table 1).
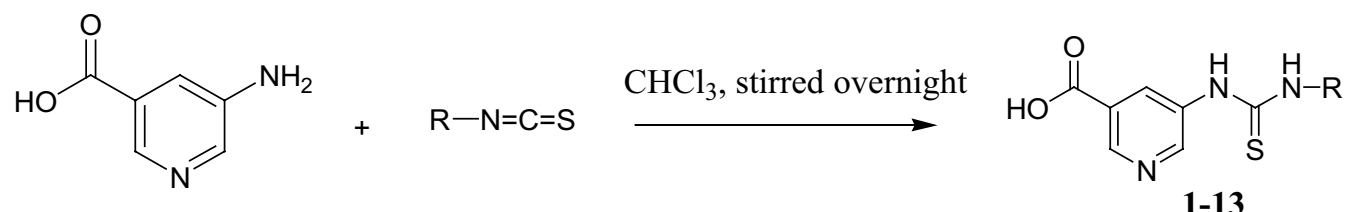

Scheme 1 Synthesis of 5-amino-nicotinic acid thioureas derivatives (1-13) 
Table 1 a-Amylase and a-glucosidase inhibition studies of compounds 1-13 with their CDOCKER interaction energy in $\mathbf{k J} / \mathrm{mol}$

\begin{tabular}{|c|c|c|c|c|c|}
\hline No. & $\mathbf{R}$ & $\begin{array}{l}\text { a-Amylase inhibition } \\
(\mu \mathrm{g} / \mathrm{mL} \pm \mathrm{SEM})\end{array}$ & $\begin{array}{l}\text { CDOCKER interaction } \\
\text { energy in } \mathrm{kJ} / \mathrm{mol}\end{array}$ & $\begin{array}{l}\text { a-Glucosidase inhibition } \\
(\mu \mathrm{g} / \mathrm{mL} \pm \mathrm{SEM})\end{array}$ & $\begin{array}{l}\text { CDOCKER } \\
\text { interaction energy } \\
\text { in } \mathrm{kJ} / \mathrm{mol}\end{array}$ \\
\hline 1 & & $28.89 \pm 0.102$ & -37.95 & $28.09 \pm 0.09$ & -38.30 \\
\hline 2 & & $12.91 \pm 0.04$ & -42.02 & $12.72 \pm 0.12$ & -42.16 \\
\hline 3 & & $28.84 \pm 0.03$ & -37.45 & $28.61 \pm 0.11$ & -37.87 \\
\hline 4 & & $12.17 \pm 0.14$ & -43.02 & $12.01 \pm 0.09$ & -43.23 \\
\hline 5 & & $13.57 \pm 0.17$ & -39.45 & $13.68 \pm 0.36$ & -39.05 \\
\hline 6 & & $13.01 \pm 0.07$ & -40.56 & $13.11 \pm 0.15$ & -39.42 \\
\hline 7 & & $12.91 \pm 0.08$ & -42.01 & $12.79 \pm 0.17$ & -42.31 \\
\hline 8 & & $13.04 \pm 0.02$ & -40.19 & $12.99 \pm 0.09$ & -41.03 \\
\hline 9 & & $26.53 \pm 0.08$ & -40.20 & $26.27 \pm 0.18$ & -40.95 \\
\hline 10 & & $26.7 \pm 0.06$ & -39.85 & $25.97 \pm 0.19$ & -40.82 \\
\hline 11 & & $26.94 \pm 0.02$ & -39.85 & $27.02 \pm 0.11$ & -40.03 \\
\hline
\end{tabular}


Table 1 (continued)

\begin{tabular}{|c|c|c|c|c|c|}
\hline No. & $\mathbf{R}$ & $\begin{array}{l}\text { a-Amylase inhibition } \\
(\mu \mathrm{g} / \mathrm{mL} \pm \mathrm{SEM})\end{array}$ & $\begin{array}{l}\text { CDOCKER interaction } \\
\text { energy in } \mathrm{kJ} / \mathrm{mol}\end{array}$ & $\begin{array}{l}\text { a-Glucosidase inhibition } \\
(\mu \mathrm{g} / \mathrm{mL} \pm \mathrm{SEM})\end{array}$ & $\begin{array}{l}\text { CDOCKER } \\
\text { interaction energy } \\
\text { in } \mathrm{kJ} / \mathrm{mol}\end{array}$ \\
\hline 12 & & $37.33 \pm 0.02$ & -39.89 & $38.01 \pm 0.12$ & -39.48 \\
\hline 13 & & $36.65 \pm 0.03$ & -39.76 & $37.47 \pm 0.13$ & -39.38 \\
\hline Acarbose & & $10.98 \pm 0.03$ & -44.30 & $10.79 \pm 0.17$ & -44.79 \\
\hline
\end{tabular}

\section{a-Glucosidase inhibitory activity}

Compounds (1-13) were tested for their potential $\alpha$-glucosidase inhibitory action. $\mathrm{IC}_{50}$ values for $\alpha$-glucosidase activity ranged between $12.01 \pm 0.09$ to $38.01 \pm 0.12 \mu \mathrm{g} / \mathrm{mL} \pm \mathrm{SEM}$. Compound $\mathbf{2}$ and 4-8 revealed significant activities for $\alpha$-glucosidase inhibition with $\mathrm{IC}_{50}$ values $12.72 \pm 0.12,12.01 \pm 0.09,13.68 \pm 0.36$, $13.11 \pm 0.15, \quad 12.79 \pm 0.17$, and $12.99 \pm 0.09 \mu \mathrm{g} /$ $\mathrm{mL} \pm \mathrm{SEM}$, respectively. Structure activity relationship of the compounds (1-13) is also conversed. The compounds 4, 2 and 7 perceived significant $\alpha$-glucosidase inhibition with $\mathrm{IC}_{50}$ values $12.01 \pm 0.09,12.72 \pm 0.12$, and $12.79 \pm 0.17 \mu \mathrm{g} / \mathrm{mL} \pm \mathrm{SEM}$, respectively. It is evident that the presence of halogens $(\mathrm{F}, \mathrm{Cl}$ and $\mathrm{Br}$ ) at the ring's para position is more ideal for potential $\alpha$-amylase inhibition as compare with other substituents. It is also noticed that compounds bearing trifluoro (compound 8), methoxy (Compound 6), and nitro group (compound 5) also revealed $\alpha$-amylase inhibition with $\mathrm{IC}_{50}$ value $12.99 \pm 0.09,13.11 \pm 0.15$ and $13.68 \pm 0.36 \mu \mathrm{g} / \mathrm{mL} \pm \mathrm{SEM}$, respectively. Conversely, unsubstituted, di-substituted and ortho/meta substituents compounds (1, 3, and 9-13) didn't demonstrate remarkable $\alpha$-glucosidase inhibition activity (Table 1 ).

\section{Molecular docking a-Amylase docking study}

Initially, the docking studies were validated by superimposing the co-crystallized ligand (Montbretin A) with extracted Montbretin A from crystal structure and redocked to amylase crystal structure (pdb id: 4W93). The calculated RMSD value between the X-ray Montbretin A (green) and redocked Montbretin A (gray) was $1.69 \AA$ as shown in below Fig. 1a. Similarly, the superimposed the co-crystallized ligand in blue (Acarbose) with extracted Acarbose (pink color) redocked to $\alpha$-glucosidase crystal structure (pdb id: 3TOP) and their RMSD value was $1.26 \AA$ (Fig. 1b).

The CDOCKER interaction energy of 5-amino-nicotinic acid derivatives is reported in Table 1 . The interaction energy $-42.01 \mathrm{~kJ} / \mathrm{mol}$ and $-42.31 \mathrm{~kJ} / \mathrm{mol}$ of the standard drug Montbretin A and acarbose for amylase and $\alpha$-glucosidase was more stable than the 5-amino-nicotinic acid derivatives.

The docking studies show the binding model of the four highest active compounds in 5-amino-nicotinic acid thioureas derivatives, binding to the Montbretin A binding site of the alpha amylase. Figure 2a, illustrates the binding mode of the compound 2 , showing that the cholorbenzene interacts with D197 and forms hydrophobic contact with W58 and Y62. While, the amine group forms hydrogen bond and salt bridge with D300, respectively. The pyridine-3-carboxylate group contacts with D197 via hydrogen bonding.

In the study of the binding properties of the compound 2 (Fig. 2b) the chlorophenyl group forms both alkyl and pi-alkyl contact with A307. While two amine linkers form salt bridge and hydrogen bond contact with D300, respectively. The pyridine ring forms pi-anion contact and carbon hydrogen bond with E233. Finally, the carboxylate moiety forms hydrogen bond with sidechain of R195 and H299. The group also forms electrostatic pi-anion contact with Y62 and salt bridge with R195. Meanwhile, Fig. 2c shows the binding properties of the compound 7, where the bromo group undergoes hydrophobic contact with L162 and L165. The amine moiety forms salt bridge with D300. The pyridine ring forms pisigma contact with I235 and pi-alkyl contact with A307. On the other hand, the carboxylate moiety forms hydrogen bond with sidechain of $\mathrm{K} 200$ and H201, it also forms electrostatic interaction with K200. 

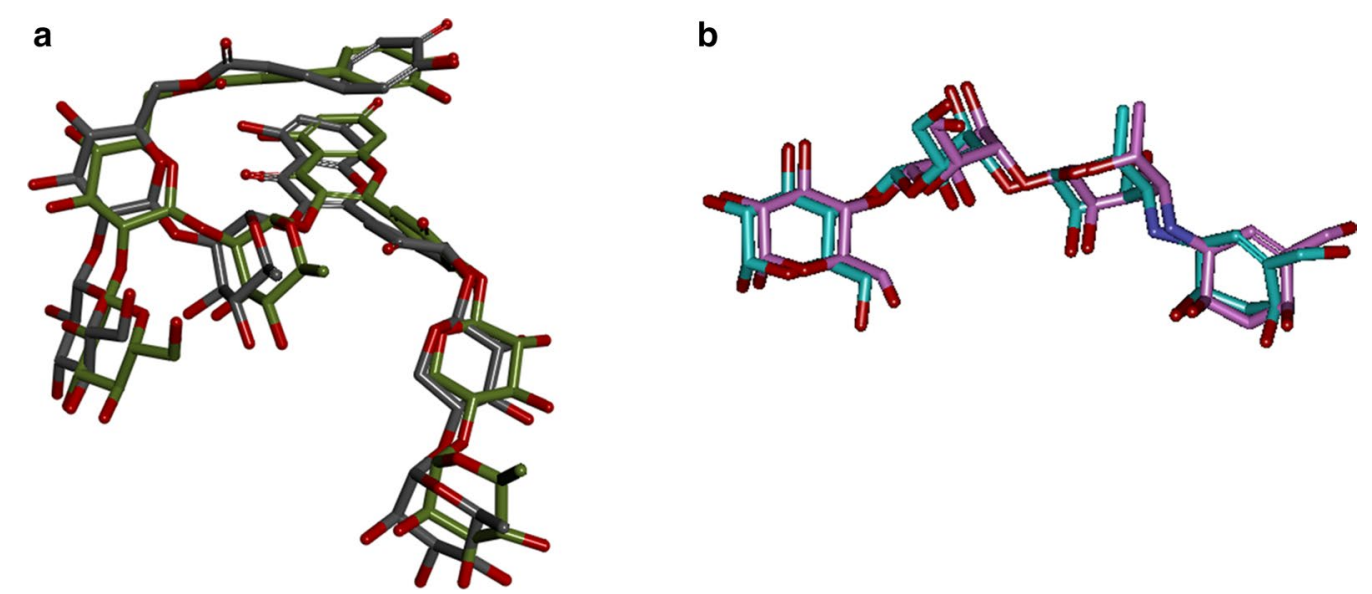

Fig. 1 a lllustrates the superimposed the co-crystallized ligand in green (Montbretin A) with extracted Montbretin A (gray color) redocked to amylase crystal structure (pdb id: 4W93). b Illustrates the superimposed the co-crystallized ligand in blue (Acarbose) with extracted Acarbose (pink color) redocked to a-glucosidase crystal structure (pdb id: 3TOP)
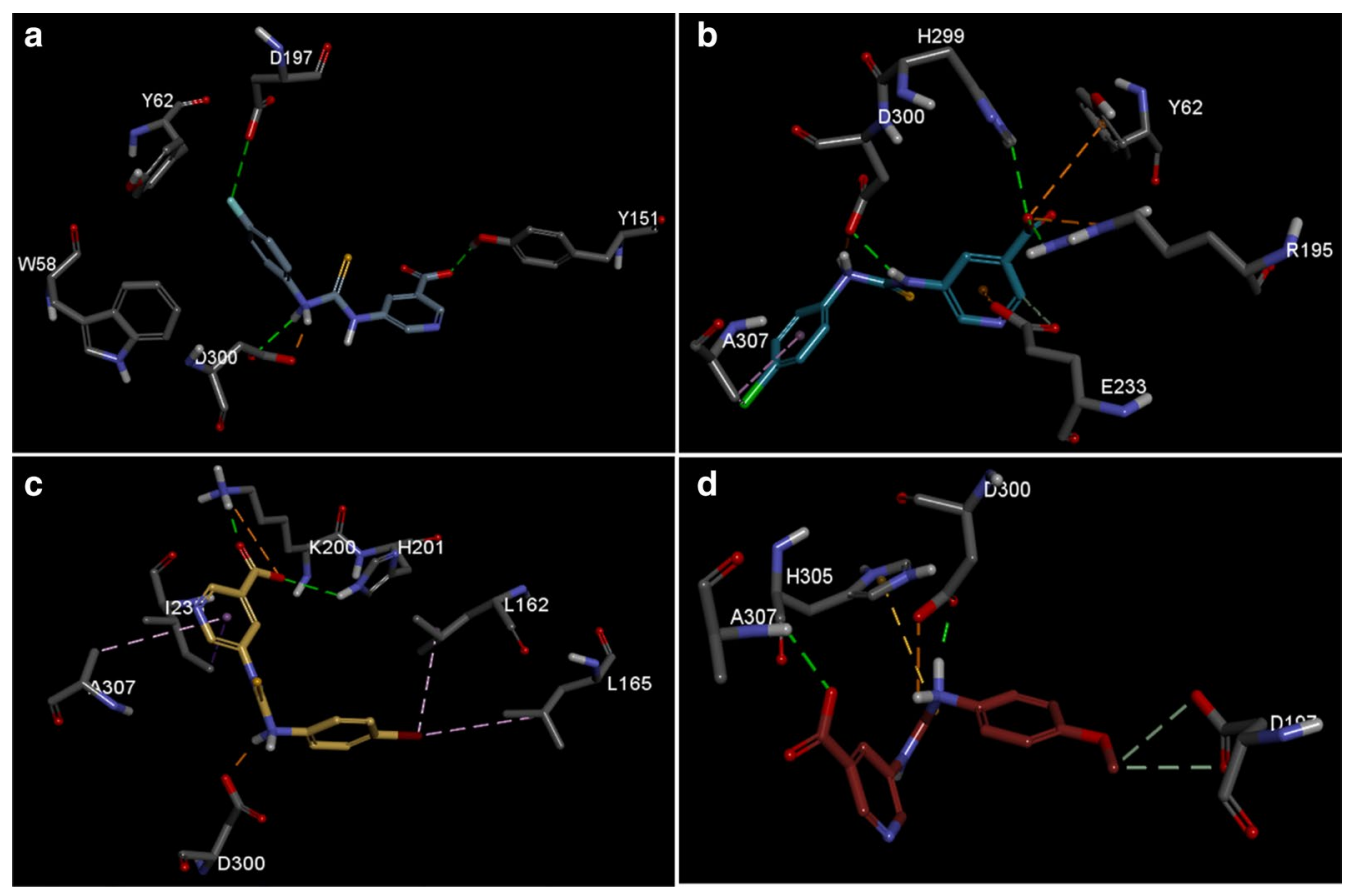

Fig. 2 Illustrates the binding mode of 5-amino-nicotinic acid derivatives active compounds in a-amylase binding site. $\mathbf{a}$ Compound $\mathbf{4}$, $\mathbf{b}$ compound $\mathbf{2}, \mathbf{c}$ Compound $\mathbf{7}$ and $\mathbf{d}$ compound $\mathbf{6}$. Key interaction types are represented in color code in each case (green: hydrogen bond, purple: alkyl contact, brown: pi stacking)

In the case of the fourth most active compound 6 the methoxy group forms carbon-based hydrogen bond with D197. The amine group forms both hydrogen bond and salt bridge with D300. This time the sulfur group forms pi-sulfur contact H305 and finally there is a hydrogen bond observed between the backbone nitrogen of A307 and carboxylate moiety (Fig. 2d).

Thus over all in this class of compound the presence of nonpolar groups as substituent was key responsible for establishing the notable interaction between 
5-amino-nicotinic acid derivatives and the key residues on the active site of the alpha amylase, eventually reflecting in the biological activity profile.

\section{a-Glucosidase docking study}

Binding mode of compound $\mathbf{4}$ is shown in Fig. 3a, where the fluoro group of the fluorophenyl ring forms halogen contact with Asp1526 and the ring of the system, as well as form pi-sulfur interaction in conjunction with Met1421 and pi-pi T-shaped stacking with Trp1355.
The $\mathrm{NH}$ group linking the carbamothioyl and amino group forms hydrogen bond with Asp1157 and attractive charge interaction with the same group. The thiol group also forms pi-sulfur contact with Trp1369. On the other end the pyridine-3-carboxylate forms pi-pi stacking with Phe1560 and carbon hydrogen bonding with Pro1159. The carboxylate oxygen forms salt bridge with Arg1156 and Lys1460.

Figure $3 \mathrm{~b}$ shows the binding mode of compound 2, the chloro group of the chlorophenyl forms pi-alkyl

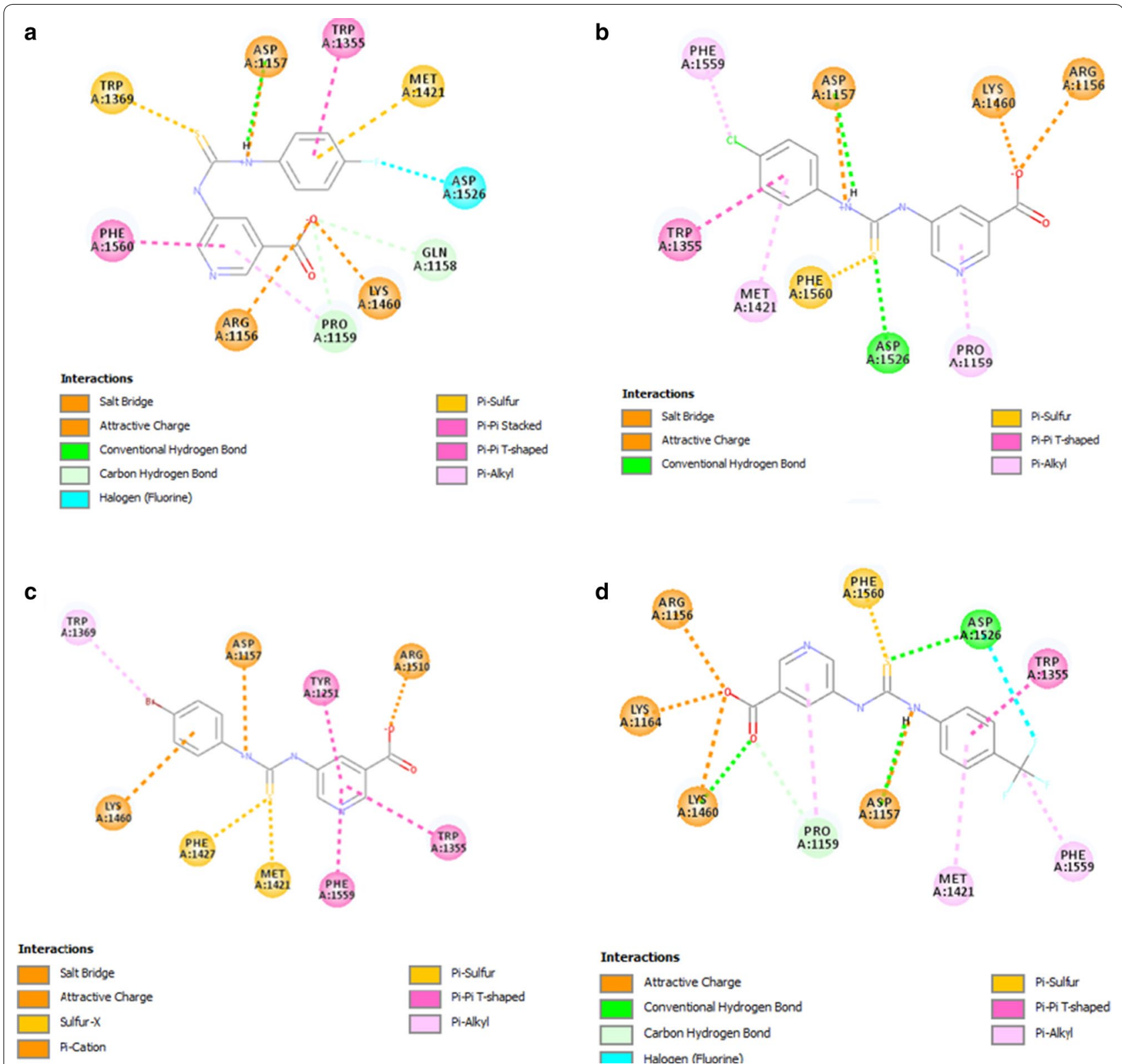

Fig. 3 Illustrates the binding mode of 5-amino-nicotinic acid derivatives active compounds in a-glucosidase. a Compound $\mathbf{4}$, $\mathbf{b}$ compound $\mathbf{2}$, $\mathbf{c}$ Compound $\mathbf{7}$ and $\mathbf{d}$ compound $\mathbf{8}$. Key interaction types are represented in color code in each case 
interaction with Phe1159 and the phenyl ring forms both pi-pi and pi-T-shaped interaction with Met1421 and Trp1355. Likewise in compound 4 the $\mathrm{NH}$ group forms both attractive and hydrogen bond interaction with Asp1157. The thiol group forms pi-sulfur contact with Phe1560 and hydrogen bond with Asp1526. The pyridine-3-carboxylate moiety forms pi-alkyl contact with Pro1159 and the carboxyl group forms salt bridge with Arg1156 and Lys1460, respectively.

In the case of the compound 7 , which contains a bromophenyl moiety, pi-alkyl interaction was observed with Trp1369 and pi-cation interaction between the ring of the bromophenyl group and Lys1460. The NH of the linker forms attractive charge with Asp1157 and on the other hand the thiol group forms pi-sulfur interaction with Phe1427 and Met1421. Likewise, in the other two above active compounds the pyridine-3-carboxylate moiety forms pi-pi interaction with Tyr1251, Trp1355 and Phe1559, respectively. In addition, the carboxylate group forms salt bridge with Arg1510 (Fig. 3c).

Binding mode of compound $\mathbf{8}$ is shown in Fig. 3d. The ring of trifluoromethylphenyl forms both pi-alkyl and pipi T-shaped stacking with Met1421 and Trp1355, while the fluoro group forms halogen contact and the methyl forms pi-alkyl interaction, correspondingly. Likewise, the $\mathrm{NH}$ group linker forms both hydrogen bond and attractive interaction with Asp1157. The thiol group connector forms pi-sulfur contact and hydrogen bond contact with Phe1560 and Asp1526, respectively. Finally, the pyridine3-carboxylate moiety forms pi-alkyl interaction with Pro1159 and the carboxyl group oxygens forms attractive charge interaction with Arg1156, Lys1164 and Lys1460. There is also a hydrogen bond between the oxygen and the Lys1460.

Thus, to conclude, we could say that the alkyl group present at the para position was mostly preferred in this class of compound, the activity was determined either by pi-alkyl contact or halogen contact with the core residues of the active site of the $\alpha$ glucosidase.

\section{Conclusion}

5-Amino-nicotinic acid derivatives (1-13) have been synthesized successfully and assessed for their action against $\alpha$-amylase and $\alpha$-glucosidase. Compounds 2, and 4-8 revealed major activities for $\alpha$-amylase and $\alpha$-glucosidase inhibition. This study identifies new class of compounds as $\alpha$-amylase and $\alpha$-glucosidase inhibitors.

\section{Experimental}

\section{Materials and methods}

All chemicals and enzymes ( $\alpha$-amylase and $\alpha$-glucosidase enzyme) used in this study were purchase from Sigma Aldrich. Avance Bruker $500 \mathrm{MHz}$ has been used for carrying out ${ }^{1} \mathrm{H}-\mathrm{NMR}$ and ${ }^{13} \mathrm{C}-\mathrm{NMR}$. FTIR (PerkinElmer) was employed to study the functional groups of the compounds. HR-MS were determined on Agilent 6330 Ion Trap using positive/negative mode. Elemental analysis was performed using PerkinElmer instrument. Melting point was recorded on Stuart (SMP-10) melting point apparatus. Pre-coated silica gel aluminum foils (Germany) were utilized for execution of thin layer chromatography (TLC). UV lamp was used for visualizing chromatograms.

\section{a-Amylase inhibitory activity}

The inhibition of $\alpha$-amylase was established by the methods described earlier [21, 22]. Incubation of $500 \mu \mathrm{L}$ of test sample $(1-100 \mu \mathrm{g} / \mathrm{mL})$ along with $500 \mu \mathrm{L}$ of $\alpha$-amylase $(0.5 \mathrm{mg} / \mathrm{mL}$ in phosphate buffer; $0.2 \mathrm{mM}$ maintained at $\mathrm{pH}$ 6.9) was carried out for $10 \mathrm{~min}$ at $25^{\circ} \mathrm{C}$. After preincubation, $1 \%$ starch solution was added $(500 \mu \mathrm{L}$, in $0.2 \mathrm{mM}$ phosphate buffer maintained at $\mathrm{pH}$ 6.9) and incubated at $25{ }^{\circ} \mathrm{C}$ for another $10 \mathrm{~min}$. The reaction was brought to arrest by using $1 \mathrm{~mL}$ of di-nitro-salicylic acid color reagent. The tubes were afterwards refluxed for $5 \mathrm{~min}$ and then cooled at ambient temperature. Resulting solutions, after diluted with $10 \mathrm{~mL}$ of distilled water, were analyzed at $540 \mathrm{~nm}$ by recording absorbance [23]. Acarbose was used as the standard drug.

The percentage of inhibition was estimated by employing the formula;

$$
\%_{\text {Inhibition }}=\left(\mathrm{A}_{\text {Control }}-\mathrm{A}_{\text {Sample }}\right) / \mathrm{A}_{\text {Control }} \times 100 .
$$

The optimum concentration needed to hydrolyze the $\alpha$-amylase by $50 \%$ ( $\mathrm{IC}_{50}$ values) was computed via non-linear regression plot of \% inhibition at $\mathrm{x}$ axis and concentrations at $y$ axis, with the help of Graph Pad Prism Software (Ver. 5).

\section{a-Glucosidase activity}

The inhibition of $\alpha$-glucosidase was established with the help of the modified version of the published technique [24]. $\alpha$-glucosidase solution was prepared by dissolving $1 \mathrm{mg}$ in $100 \mathrm{~mL}$ phosphate buffer (pH 6.8) comprising of $200 \mathrm{mg}$ bovine serum albumin. $10 \mu \mathrm{L}$ of sample at variable concentrations ( 1 to $100 \mu \mathrm{g} / \mathrm{mL}$ ) was pre-mixed with $490 \mu \mathrm{L}$ phosphate buffer ( $\mathrm{pH}$ 6.8), and to this reaction mixture was added $250 \mu \mathrm{L}$ of $5 \mathrm{mM}$ p-nitrophenyl $\alpha$-D-glucopyranoside and preincubated at $37{ }^{\circ} \mathrm{C}$. After $5 \mathrm{~min}$, addition of $250 \mu \mathrm{L} \alpha$-glucosidase $(0.15 \mathrm{unit} / \mathrm{mL})$ was done with further incubation at $37{ }^{\circ} \mathrm{C}$ for $15 \mathrm{~min}$. The inhibition was concluded by adding $2000 \mu \mathrm{L}$ of $\mathrm{Na}_{2} \mathrm{CO}_{3}(200 \mathrm{mM}) . \alpha$-Glucosidase activity was computed at $400 \mathrm{~nm}$ on Shimadzu $265 \mathrm{UV}$-Vis spectrophotometer (Japan) by computing the amount of $p$-nitrophenol 
released from p-NPG, using acarbose as positive control. The optimum concentration needed to hydrolyze $50 \%$ of $\alpha$-glucosidase was defined as the $\mathrm{IC}_{50}$ value.

The percentage of inhibition was estimated by employing the formula;

$$
\%_{\text {Inhibition }}=\left(\mathrm{A}_{\text {Control }}-\mathrm{A}_{\text {Sample }}\right) / \mathrm{A}_{\text {Control }} \times 100 .
$$

\section{Statistical analysis}

The concentration required to inhibit the $\alpha$-amylase by $50 \%$ ( $\mathrm{IC}_{50}$ values) were computed via non-linear regression plot between percentage inhibition at the $\mathrm{x}$ axis and concentrations at $y$ axis, with the help of Graph Pad Prism Software (Ver. 5).

\section{Computational docking methodology Computational docking studies of a-amylase and a-glucosidase}

With the aim of revealing the binding properties of the all the 5-amino-nicotinic acid derivatives in $\alpha$-amylase (pdb id: 4w93) [25] and in $\alpha$-glucosidase (pdb id: 3top) [26], molecular docking studies were done using CDOCKER implemented in Discovery studio.CDOCKER is a gridbased method of molecular docking that make use of CHARMM force field [27]. The Montbretin A binding site in $\alpha$-amylase crystal structure was defined as binding site for docking the compounds. Similarly the acarbose binding site in $\alpha$-glucosidase crystal structure was defied as the binding site to dock the compounds. Prior to docking both enzymes and the 5-amino-nicotinic acid derivatives were structurally optimized by adding hydrogen and atom valencies were satisfied so that atoms are properly typed. After the binding site sphere was defined, docking calculation was subsequently done. Top 10 binding pose were opted for prediction and results were analysed using Discovery studio visualizer.

\section{General procedure for synthesis of 5-amino-nicotinic acid derivatives}

1 mmol of 5-amino-nicotinic acid was weighed and transfer into $50 \mathrm{~mL}$ round bottomed flask, then $1.2 \mathrm{mmol}$ of phenyl isothiocyanate (Table 1) was added, followed by the addition of $10 \mathrm{~mL}$ of chloroform. The reaction mixture was left overnight with stirring and was monitored by TLC. After the reaction was completed, the product was transferred into beakers and evaporated at room temperature. Diethyl ether was used to wash the solid product.

\section{5-(3-Phenylthioureido)pyridine-3-carboxylic acid (1)}

Yield: 76\%; M.p.: $>300{ }^{\circ} \mathrm{C}$; FTIR (ATR, $\mathrm{cm}^{-1}$ ): 3332 (N-H), 3190 (Ar-CH), $1654(\mathrm{C}=\mathrm{O}), 1586(\mathrm{C}-\mathrm{N}), 1488$
$(\mathrm{C}=\mathrm{C}), 1330(\mathrm{C}=\mathrm{S}) ;{ }^{1} \mathrm{HNMR}\left(500 \mathrm{MHz}, \mathrm{DMSO}-d_{6}\right): \delta$ 12.16 (s, 1H, NH), 11.50 (s, 1H, NH), 8.86 (s, 1H, H-2), 8.62 (s, 1H, H-6), 7.69 (s, 1H, H-4), 7.06-6.94 (m, 5H, $\mathrm{H}-2^{\prime}$ to $\mathrm{H}-5^{\prime}$ ), 3.60 (br. s, $\left.1 \mathrm{H}, \mathrm{OH}\right) ;{ }^{13} \mathrm{CNMR}(125 \mathrm{MHz}$, DMSO- $\left.d_{6}\right): \delta 179.6(\mathrm{C}=\mathrm{S}), 169.0(\mathrm{C}=\mathrm{O}), 141.2(\mathrm{C} 2)$, 140.5 (C6), $137.0\left(\mathrm{C}^{\prime}\right), 134.2$ (C5), $129.0\left(\mathrm{C}^{\prime}\right) 129.0\left(\mathrm{C}^{\prime}\right)$, 128.4 (C3), 126.4 (C2'), 126.4 (C6'), 124.3 (C4'), 122.8 (C4); HR-MS for $\mathrm{C}_{13} \mathrm{H}_{11} \mathrm{~N}_{3} \mathrm{O}_{2} \mathrm{~S}$ calculated 273.0572 and found 273.0549; Anal. calcd. for $\mathrm{C}_{13} \mathrm{H}_{11} \mathrm{~N}_{3} \mathrm{O}_{2} \mathrm{~S}$ : C, 57.13; $\mathrm{H}, 4.06$; N, 15.37; O, 11.71; S, 11.73; found: C, 57.11; $\mathrm{H}$, $4.05 ; \mathrm{N}, 15.36 ; \mathrm{O}, 11.70 ; \mathrm{S}, 11.72$.

\section{5-(3-(4-Chlorophenyl)thioureido)pyridine-3-carboxylic acid} (2)

Yield: 72\%; M.p.: $>300{ }^{\circ} \mathrm{C}$; FTIR (ATR, $\mathrm{cm}^{-1}$ ): 3334 (N-H), 3191 (Ar-CH), $1655(\mathrm{C}=\mathrm{O}), 1587(\mathrm{C}-\mathrm{N}), 1469$ $(\mathrm{C}=\mathrm{C}), \quad 1331(\mathrm{C}=\mathrm{S}), \quad 785(\mathrm{C}-\mathrm{Cl}) ;{ }^{1} \mathrm{HNMR}(500 \mathrm{MHz}$, DMSO- $\left.d_{6}\right): \delta 11.50(\mathrm{~s}, 1 \mathrm{H}, \mathrm{NH}), 11.30(\mathrm{~s}, 1 \mathrm{H}, \mathrm{NH}), 8.85$ (s, 1H, H-2), 8.60 (s, 1H, H-6), 7.62 (s, 1H, H-4), 7.03 (d, $\left.J=8.0 \mathrm{~Hz}, 2 \mathrm{H}, \mathrm{H}-2^{\prime}, \mathrm{H}-6^{\prime}\right), 6.40\left(\mathrm{~d}, J=8.0 \mathrm{~Hz}, \mathrm{H}-3^{\prime}, \mathrm{H}-5^{\prime}\right)$, 3.58 (br. s, $1 \mathrm{H}, \mathrm{OH}) ;{ }^{13} \mathrm{CNMR}\left(125 \mathrm{MHz}, \mathrm{DMSO}-d_{6}\right): \delta$ 179.5 (C=S), 169.0 (C=O), 141.1 (C2), 140.0 (C6), 135.0 (C1'), 134.3 (C5), 130.1(C4'), $129.0\left(\mathrm{C}^{\prime}\right), 129.0\left(\mathrm{C}^{\prime}\right)$, 128.8 (C3), 127.5 (C 2'), 127.5 (C6'), 123.3 (C4); HR-MS for $\mathrm{C}_{13} \mathrm{H}_{10} \mathrm{ClN}_{3} \mathrm{O}_{2} \mathrm{~S}$ calculated 307.0182 and found 307.0171; Anal. calcd. for $\mathrm{C}_{13} \mathrm{H}_{10} \mathrm{ClN}_{3} \mathrm{O}_{2} \mathrm{~S}$ : C, 50.73; $\mathrm{H}$, 3.28; N, 13.65; O, 10.40; S, 10.42. Found: C, 50.72; H, 3.26; N, 13.64; O, 10.39; S, 10.41 .

\section{5-(3-p-Tolylthioureido)pyridine-3-carboxylic acid (3)}

Yield: 79\%; M.p.: $>300{ }^{\circ} \mathrm{C}$; FTIR (ATR, $\mathrm{cm}^{-1}$ ): 3334 $(\mathrm{N}-\mathrm{H}), 3191$ (Ar-CH), $1655(\mathrm{C}=\mathrm{O}), 1586(\mathrm{C}-\mathrm{N})$, $1468(\mathrm{C}=\mathrm{C}), 1331(\mathrm{C}=\mathrm{S})$. HR-MS; ${ }^{1} \mathrm{HNMR}(500 \mathrm{MHz}$, DMSO- $\left.d_{6}\right): \delta 11.80(\mathrm{~s}, 1 \mathrm{H}, \mathrm{NH}), 11.10(\mathrm{~s}, 1 \mathrm{H}, \mathrm{NH}), 8.87$ (s, 1H, H-2), 8.61(s, 1H, H-6), 7.61 (s, 1H, H-4), 6.80 (d, $\left.J=8.5 \mathrm{~Hz}, 2 \mathrm{H}, \mathrm{H}-3^{\prime}, \mathrm{H}-5^{\prime}\right), 6.32\left(\mathrm{~d}, J=8.5 \mathrm{~Hz}, 2 \mathrm{H}, \mathrm{H}-2^{\prime}\right.$, $\mathrm{H}^{-6} 6^{\prime}$ ), 3.62 (br. s, $\left.1 \mathrm{H}, \mathrm{OH}\right), 2.46$ (s, 3H, $\left.\mathrm{CH}_{3}\right) ;{ }^{13} \mathrm{CNMR}$ $\left(125 \mathrm{MHz}, \mathrm{DMSO}-d_{6}\right): \delta 179.3(\mathrm{C}=\mathrm{S}), 169.3(\mathrm{C}=\mathrm{O})$, 141.2 (C2), 140.2 (C6), $134.3\left(\mathrm{C}^{\prime}\right), 134.2\left(\mathrm{C}^{\prime}\right), 134.0$ (C5), $129.2\left(\mathrm{C}^{\prime}\right), 129.2\left(\mathrm{C}^{\prime}\right), 128.5(\mathrm{C} 3), 127.0\left(\mathrm{C}^{\prime}\right)$, $127.0\left(\mathrm{C6}^{\prime}\right), 123.1$ (C4), $24.2\left(\mathrm{CH}_{3}\right)$; for $\mathrm{C}_{14} \mathrm{H}_{13} \mathrm{~N}_{3} \mathrm{O}_{2} \mathrm{~S}$ calculated 287.0728 and found 287.0717; Anal. calcd. for $\mathrm{C}_{14} \mathrm{H}_{13} \mathrm{~N}_{3} \mathrm{O}_{2} \mathrm{~S}$ : C, 58.52; $\mathrm{H}, 4.56 ; \mathrm{N}, 14.62 ; \mathrm{O}, 11.14 ; \mathrm{S}$, 11.16 found: $\mathrm{C}, 58.50 ; \mathrm{H}, 4.55 ; \mathrm{N}, 14.60 ; \mathrm{O}, 11.13 ; \mathrm{S}, 11.15$.

\section{5-(3-(4-Fluorophenyl)thioureido)pyridine-3-carboxylic acid}

(4)

Yield: 75\%; M.p.:>300 ${ }^{\circ} \mathrm{C}$; FTIR (ATR, $\left.\mathrm{cm}^{-1}\right)$ : 3334 $(\mathrm{N}-\mathrm{H}), 3191$ (Ar-CH), $1655(\mathrm{C}=\mathrm{O}), 1586(\mathrm{C}-\mathrm{N})$, 1469(C=C), 1331 (C=S), 785 (C-F); ${ }^{1} \mathrm{HNMR}(500 \mathrm{MHz}$, DMSO- $\left.d_{6}\right): \delta 11.50(\mathrm{~s}, 1 \mathrm{H}, \mathrm{NH}), 11.15(\mathrm{~s}, 1 \mathrm{H}, \mathrm{NH}), 8.86$ (s, 1H, H-2), 8.62 (s, 1H, H-6), 7.62 (s, 1H, H-4), 6.72 (d, $\left.J=7.5 \mathrm{~Hz}, 2 \mathrm{H}, \mathrm{H}-3^{\prime}, \mathrm{H}-5^{\prime}\right), 6.40\left(\mathrm{t}, J=8.5 \mathrm{~Hz}, 2 \mathrm{H}, \mathrm{H}-2^{\prime}\right.$, 
H-6'), 3.62 (br. s, $1 \mathrm{H}, \mathrm{OH}) ;{ }^{13} \mathrm{CNMR}(125 \mathrm{MHz}$, DMSO$\left.d_{6}\right): \delta 179.7(\mathrm{C}=\mathrm{S}), 169.0(\mathrm{C}=\mathrm{O}), 158.5\left(\mathrm{C} 4^{\prime}\right), 140.5(\mathrm{C} 2)$, 140.0 (C6), 134.3 (C5), $132.1\left(\mathrm{C}^{\prime}\right), 128.8\left(\mathrm{C} 2^{\prime}\right), 128.8$ (C6'), 128.3 (C3), $115.6\left(\mathrm{C}^{\prime}\right)$, $115.6\left(\mathrm{C}^{\prime}\right), 123.2$ (C4); HR-MS for $\mathrm{C}_{13} \mathrm{H}_{10} \mathrm{FN}_{3} \mathrm{O}_{2} \mathrm{~S}$ calculated 291.0478 and found 291.0463; Anal. calcd. for $\mathrm{C}_{13} \mathrm{H}_{10} \mathrm{FN}_{3} \mathrm{O}_{2} \mathrm{~S}$ : C, 53.60; $\mathrm{H}, 3.46$; N, 14.42; O, 10.98; S, 11.01; found: C, 53.59; $\mathrm{H}$, $3.44 ; \mathrm{N}, 14.41 ; \mathrm{O}, 10.97 ; \mathrm{S}, 11.01$.

\section{5-(3-(4-Nitrophenyl) thioureido) pyridine-3-carboxylic acid} (5)

Yield: 69\%; M.p.: $>300{ }^{\circ} \mathrm{C}$; FTIR (ATR, $\mathrm{cm}^{-1}$ ): 3333 $(\mathrm{N}-\mathrm{H}), 3190(\mathrm{Ar}-\mathrm{CH}), 1654(\mathrm{C}=\mathrm{O}), 1586(\mathrm{C}-\mathrm{N})$, 1468 $(\mathrm{C}=\mathrm{C}), 1330(\mathrm{C}=\mathrm{S}){ }^{1} \mathrm{H}$ HMR $(500 \mathrm{MHz}$, DMSO$\left.d_{6}\right): \delta 11.42(\mathrm{~s}, 1 \mathrm{H}, \mathrm{NH}), 11.02(\mathrm{~s}, 1 \mathrm{H}, \mathrm{NH}), 8.86(\mathrm{~s}, 1 \mathrm{H}$, $\mathrm{H}-2), 8.60$ (s, $1 \mathrm{H}, \mathrm{H}-6), 7.90$ (d, $J=8.0 \mathrm{~Hz}, 2 \mathrm{H}, \mathrm{H}-3^{\prime}$, H-5') 7.58 (s, $1 \mathrm{H}, \mathrm{H}-4), 6.68$ (d, $J=8.0 \mathrm{~Hz}, 2 \mathrm{H}, \mathrm{H}-2^{\prime}$, H-6'), 3.60 (br. s, $1 \mathrm{H}, \mathrm{OH}) ;{ }^{13} \mathrm{CNMR}(125 \mathrm{MHz}$, DMSO$\left.d_{6}\right)$ : $\delta 179.6(\mathrm{C}=\mathrm{S}), 169.2(\mathrm{C}=\mathrm{O}), 144.5\left(\mathrm{C} 4^{\prime}\right), 143.4\left(\mathrm{C}^{\prime}\right)$, 140.5 (C2), 140.0 (C6), 133.9 (C5), 128.9 (C3), 127.2 (C2'), $127.2\left(\mathrm{C}^{\prime}\right), 121.2\left(\mathrm{C}^{\prime}\right), 121.2\left(\mathrm{C}^{\prime}\right), 123.1(\mathrm{C} 4)$;HRMS for $\mathrm{C}_{13} \mathrm{H}_{10} \mathrm{~N}_{4} \mathrm{O}_{4} \mathrm{~S}$ calculated 318.0423 and found 318.0416; Anal. calcd. for $\mathrm{C}_{13} \mathrm{H}_{10} \mathrm{~N}_{4} \mathrm{O}_{4} \mathrm{~S}: \mathrm{C}, 49.05 ; \mathrm{H}, 3.17$; $\mathrm{N}, 17.60 ; \mathrm{O}, 20.11 ; \mathrm{S}, 10.07$; found: C, 49.03; H, 3.16; N, 17.58; O, 20.10; S, 10.06 .

\section{5-(3-(4-Methoxyphenyl) thioureido) pyridine-3-carboxylic acid (6)}

Yield: 77\%; M.p.: $>300{ }^{\circ} \mathrm{C}$; FTIR (ATR, $\mathrm{cm}^{-1}$ ): 3333 $(\mathrm{N}-\mathrm{H}), 3190(\mathrm{Ar}-\mathrm{CH}), 1654(\mathrm{C}=\mathrm{O}), 1586(\mathrm{C}-\mathrm{N})$, 1468 $(\mathrm{C}=\mathrm{C}), \quad 1330(\mathrm{C}=\mathrm{S}), 1089(\mathrm{Ar}-\mathrm{O}-\mathrm{C}) ; \quad{ }^{1} \mathrm{HNMR}$ $\left(500 \mathrm{MHz}, \mathrm{DMSO}-d_{6}\right): \delta 11.42(\mathrm{~s}, 1 \mathrm{H}, \mathrm{NH}), 11.05(\mathrm{~s}$, $1 \mathrm{H}, \mathrm{NH}), 8.86$ (s, 1H, H-2), 8.60 (s, 1H, H-6), 7.59 (s, $1 \mathrm{H}, \mathrm{H}-4), 6.52\left(\mathrm{~d}, J=8.0 \mathrm{~Hz}, 2 \mathrm{H}, \mathrm{H}-3^{\prime}, \mathrm{H}-5^{\prime}\right), 6.37$ (d, $\left.J=8.0 \mathrm{~Hz}, 2 \mathrm{H}, \mathrm{H}-2^{\prime}, \mathrm{H}-6^{\prime}\right), 3.80$ (s, $\left.3 \mathrm{H}, \mathrm{OCH}_{3}\right) 3.60$ (br. s, $1 \mathrm{H}, \mathrm{OH}) ;{ }^{13} \mathrm{CNMR}\left(125 \mathrm{MHz}, \mathrm{DMSO}-d_{6}\right): \delta 179.6$ $(\mathrm{C}=\mathrm{S}), 169.0(\mathrm{C}=\mathrm{O}), 156.4\left(\mathrm{C} 4^{\prime}\right), 140.5(\mathrm{C} 2), 140.0(\mathrm{C} 6)$, 134.2 (C5), $129.2\left(\mathrm{C}^{\prime}\right), 128.9$ (C3), $127.3\left(\mathrm{C} 2^{\prime}\right), 127.3$ (C6'), $123.1(\mathrm{C} 4), 114.2\left(\mathrm{C}^{\prime}\right), 114.2\left(\mathrm{C}^{\prime}\right), 55.6\left(\mathrm{CH}_{3}\right)$; HR-MS for $\mathrm{C}_{14} \mathrm{H}_{13} \mathrm{~N}_{3} \mathrm{O}_{3} \mathrm{~S}$ calculated 303.0678 and found 303.0667; Anal. calcd. for $\mathrm{C}_{14} \mathrm{H}_{13} \mathrm{~N}_{3} \mathrm{O}_{3} \mathrm{~S}$ : C, 55.43; $\mathrm{H}, 4.32$; $\mathrm{N}, 13.85$; O, 15.82; S, 10.57; found: C, 55.42; H, 4.31; N, $13.83 ; \mathrm{O}, 15.81 ; \mathrm{S}, 10.56$.

\section{5-(3-(4-Bromophenyl) thioureido) pyridine-3-carboxylic acid}

(7)

Yield: 79\%; M.p.: $>300{ }^{\circ} \mathrm{C}$; FTIR (ATR, $\mathrm{cm}^{-1}$ ): 3333 $(\mathrm{N}-\mathrm{H}), 3190(\mathrm{Ar}-\mathrm{CH}), 1654(\mathrm{C}=\mathrm{O}), 1586(\mathrm{C}-\mathrm{N}), 1468$ $(\mathrm{C}=\mathrm{C}), \quad 1331(\mathrm{C}=\mathrm{S}) \quad 785(\mathrm{C}-\mathrm{Br}){ }^{1}{ }^{\mathrm{H} N M R} \quad(500 \mathrm{MHz}$, DMSO- $\left.d_{6}\right): \delta 11.70(\mathrm{~s}, 1 \mathrm{H}, \mathrm{NH}), 11.30(\mathrm{~s}, 1 \mathrm{H}, \mathrm{NH}), 8.80$ (s, 1H, H-2), $8.62(\mathrm{~s}, 1 \mathrm{H}, \mathrm{H}-6), 7.70(\mathrm{~s}, 1 \mathrm{H}, \mathrm{H}-4), 7.15$ (d, $\left.J=8.0 \mathrm{~Hz}, 2 \mathrm{H}, \mathrm{H}-3^{\prime}, \mathrm{H}-5^{\prime}\right), 6.38$ (d, $J=8.0 \mathrm{~Hz}, 2 \mathrm{H}$, H-2', H-6'), 3.64 (br. s, $1 \mathrm{H}, \mathrm{OH}) ;{ }^{13} \mathrm{CNMR}(125 \mathrm{MHz}$,
DMSO- $\left.d_{6}\right): \delta 179.6(\mathrm{C}=\mathrm{S}), 169.3(\mathrm{C}=\mathrm{O}), 140.3(\mathrm{C} 2)$, 140.1 (C6), $136.0\left(\mathrm{C}^{\prime}\right), 134.2$ (C5), 132.1 (C3'), 132.1

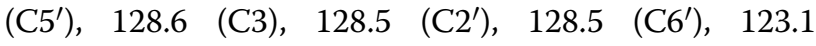
(C4), 119.2 (C4'); HR-MSfor $\mathrm{C}_{13} \mathrm{H}_{10} \mathrm{BrN}_{3} \mathrm{O}_{2} \mathrm{~S}$ calculated 350.9677 and found 350.9653; Anal. calcd. for $\mathrm{C}_{13} \mathrm{H}_{10} \mathrm{BrN}_{3} \mathrm{O}_{2} \mathrm{~S}$ : C, 44.33; $\mathrm{H}, 2.86 ; \mathrm{N}, 11.93$; O, 9.09; $\mathrm{S}$, 9.10; found: C, 44.32; H, 2.84; N, 11.92; O, 9.08; S, 9.08.

\section{5-(3-(4-(Trifluoromethyl)phenyl) thioureido) \\ pyridine-3-carboxylic acid (8)}

Yield: 72\%; M.p.: $>300{ }^{\circ} \mathrm{C}$; FTIR (ATR, $\mathrm{cm}^{-1}$ ): 3333 $(\mathrm{N}-\mathrm{H}), 3190(\mathrm{Ar}-\mathrm{CH}), 1654(\mathrm{C}=\mathrm{O}), 1586(\mathrm{C}-\mathrm{N})$, 1468 $(\mathrm{C}=\mathrm{C}), 1330(\mathrm{C}=\mathrm{S}), 785(\mathrm{C}-\mathrm{F}) ;{ }^{1} \mathrm{HNMR}(500 \mathrm{MHz}$, DMSO- $\left.d_{6}\right): \delta 11.62(\mathrm{~s}, 1 \mathrm{H}, \mathrm{NH}), 11.32(\mathrm{~s}, 1 \mathrm{H}, \mathrm{NH}), 8.72$ (s, 1H, H-2), 8.65 (s, 1H, H-6), 7.67 (s, 1H, H-4), 7.15 $\left(\mathrm{d}, J=8.0 \mathrm{~Hz}, 2 \mathrm{H}, \mathrm{H}-3^{\prime}, \mathrm{H}-5^{\prime}\right), 6.38(\mathrm{~d}, J=8.0 \mathrm{~Hz}, 2 \mathrm{H}$, H-2', H-6'), 3.68 (br. s, $1 \mathrm{H}, \mathrm{OH}) ;{ }^{13} \mathrm{CNMR}(125 \mathrm{MHz}$, DMSO- $\left.d_{6}\right): \delta 179.6(\mathrm{C}=\mathrm{S}), 169.3(\mathrm{C}=\mathrm{O}), 140.6(\mathrm{C} 2)$, 140.1 (C6), $140.0\left(\mathrm{C1}^{\prime}\right), 134.2$ (C5), 128.8 (C3), 127.3 $\left(\mathrm{CF}_{3}\right), 126.7\left(\mathrm{C} 2^{\prime}\right), 126.7\left(\mathrm{C6}^{\prime}\right), 125.5\left(\mathrm{C}^{\prime}\right), 125.5\left(\mathrm{C}^{\prime}\right)$, 124.1 (C4'), 123.1 (C4); HR-MS for $\mathrm{C}_{14} \mathrm{H}_{10} \mathrm{~F}_{3} \mathrm{~N}_{3} \mathrm{O}_{2} \mathrm{~S}$ calculated 341.0446 and found 341.0432; Anal. calcd. for $\mathrm{C}_{14} \mathrm{H}_{10} \mathrm{~F}_{3} \mathrm{~N}_{3} \mathrm{O}_{2} \mathrm{~S}: \mathrm{C}, 49.27 ; \mathrm{H}, 2.95 ; \mathrm{F}, 16.70 ; \mathrm{N}, 12.31 ; \mathrm{O}$, 9.38; S, 9.39; found: C, 49.26; H, 2.93; F, 16.69; N, 12.30; O, 9.37; S, 9.37.

\section{5-(3-(3-Chloro-4-methylphenyl) thioureido) pyridine-3-carboxylic acid (9)}

Yield: 68\%; M.p.: $>300{ }^{\circ} \mathrm{C}$; FTIR (ATR, $\mathrm{cm}^{-1}$ ): 3333 $(\mathrm{N}-\mathrm{H}), 3190(\mathrm{Ar}-\mathrm{CH}), 1654(\mathrm{C}=\mathrm{O}), 1586(\mathrm{C}-\mathrm{N})$, 1468 $(\mathrm{C}=\mathrm{C}), 1330(\mathrm{C}=\mathrm{S}), 785(\mathrm{C}-\mathrm{Cl}) ;{ }^{1} \mathrm{HNMR}(500 \mathrm{MHz}$, DMSO- $\left.d_{6}\right): \delta 11.43(\mathrm{~s}, 1 \mathrm{H}, \mathrm{NH}), 11.23(\mathrm{~s}, 1 \mathrm{H}, \mathrm{NH})$, $8.72(\mathrm{~s}, 1 \mathrm{H}, \mathrm{H}-2), 8.69$ (s, 1H, H-6), 7.61 (s, 1H, H-4), $6.74\left(\mathrm{~d}, J=7.5 \mathrm{~Hz}, 1 \mathrm{H}, \mathrm{H}-5^{\prime}\right), 6.37$ (s, $\left.1 \mathrm{H}, \mathrm{H}-2^{\prime}\right), 6.21(\mathrm{~d}$, $\left.J=8.0 \mathrm{~Hz}, 1 \mathrm{H}, \mathrm{H}-6^{\prime}\right), 3.64$ (br. s, $\left.1 \mathrm{H}, \mathrm{OH}\right), 2.38(\mathrm{~s}, 3 \mathrm{H}$, $\left.\mathrm{CH}_{3}\right) ;{ }^{13} \mathrm{CNMR}\left(125 \mathrm{MHz}, \mathrm{DMSO}-d_{6}\right): \delta 179.8(\mathrm{C}=\mathrm{S})$, $169.5(\mathrm{C}=\mathrm{O}), 140.5(\mathrm{C} 2), 140.2(\mathrm{C} 6), 135.6\left(\mathrm{C}^{\prime}\right), 134.6$ (C3'), 134.1 (C5), $132.1\left(\mathrm{C}^{\prime}\right), 130.5\left(\mathrm{C}^{\prime}\right), 128.9$ (C3), $126.7\left(\mathrm{C} 2^{\prime}\right), 124.7\left(\mathrm{C6}^{\prime}\right), 123.1(\mathrm{C} 4), 15.6\left(\mathrm{CH}_{3}\right)$; HR-MS for $\mathrm{C}_{14} \mathrm{H}_{12} \mathrm{ClN}_{3} \mathrm{O}_{2} \mathrm{~S}$ calculated 321.0339 and found 321.0327; Anal. calcd. for $\mathrm{C}_{14} \mathrm{H}_{12} \mathrm{ClN}_{3} \mathrm{O}_{2} \mathrm{~S}$ : C, 52.26; $\mathrm{H}$, 3.76; N, 13.06; O, 9.94; S, 9.96; found: C, 52.25; H, 3.75; N, 13.04; O, 9.92; S, 9.95.

\section{5-(3-(2-Fluorophenyl) thioureido) pyridine-3-carboxylic acid (10)}

Yield: 79\%; M.p.: $>300{ }^{\circ} \mathrm{C}$; FTIR (ATR, $\mathrm{cm}^{-1}$ ): 3333 $(\mathrm{N}-\mathrm{H}), 3191(\mathrm{Ar}-\mathrm{CH}), 1655(\mathrm{C}=\mathrm{O}), 1586(\mathrm{C}-\mathrm{N})$, 1469 $(\mathrm{C}=\mathrm{C}), 1331(\mathrm{C}=\mathrm{S}), 785(\mathrm{C}-\mathrm{F}) ;{ }^{1} \mathrm{HNMR}(500 \mathrm{MHz}$, DMSO- $\left.d_{6}\right): \delta 11.96(\mathrm{~s}, 1 \mathrm{H}, \mathrm{NH}), 11.38(\mathrm{~s}, 1 \mathrm{H}, \mathrm{NH}), 8.74$ (s, 1H, H-2), 8.65 (s, 1H, H-6), 7.67 (s, 1H, H-4), 6.75$6.70\left(\mathrm{~m}, 2 \mathrm{H}, \mathrm{H}-2^{\prime}, \mathrm{H}-5^{\prime}\right), 6.63-6.60\left(\mathrm{~m}, 1 \mathrm{H}, \mathrm{H}-4^{\prime}\right), 6.41$ (d, $J=7.0 \mathrm{~Hz}, 1 \mathrm{H}, \mathrm{H}-6^{\prime}$ ), 3.66 (br. s, $\left.1 \mathrm{H}, \mathrm{OH}\right) ;{ }^{13} \mathrm{CNMR}$ 
$\left(125 \mathrm{MHz}, \mathrm{DMSO}-d_{6}\right): \delta 179.8(\mathrm{C}=\mathrm{S}), 169.4(\mathrm{C}=\mathrm{O})$, 167.6 (C2'), 140.3 (C2), 140.1 (C6), 134.1 (C5), 128.8 (C3), $128.2\left(\mathrm{C}^{\prime}\right), 126.4\left(\mathrm{C}^{\prime}\right), 124.6\left(\mathrm{C}^{\prime}\right), 123.3(\mathrm{C} 4)$, $120.3\left(\mathrm{C}^{\prime}\right)$, 115.6 (C3); HR-MS for $\mathrm{C}_{13} \mathrm{H}_{10} \mathrm{FN}_{3} \mathrm{O}_{2} \mathrm{~S}$ calculated 291.0478 and found 291.0464; Anal. calcd. for $\mathrm{C}_{13} \mathrm{H}_{10} \mathrm{FN}_{3} \mathrm{O}_{2} \mathrm{~S}$ : C, 53.60; $\mathrm{H}, 3.46 ; \mathrm{N}, 14.42 ; \mathrm{O}, 10.98$; S, 11.01; found: C, 53.58; H, 3.44; N, 14.41; O, 10.97; S, 11.01 .

\section{5-(3-(3-Fluorophenyl) thioureido) pyridine-3-carboxylic acid (11)}

Yield: 75\%; M.p.: $>300{ }^{\circ} \mathrm{C}$; FTIR (ATR, $\mathrm{cm}^{-1}$ ): 3331 $(\mathrm{N}-\mathrm{H}), 3191(\mathrm{Ar}-\mathrm{CH}), 1655(\mathrm{C}=\mathrm{O}), 1587 \quad(\mathrm{C}-\mathrm{N})$, 1468 $(\mathrm{C}=\mathrm{C}), 1332(\mathrm{C}=\mathrm{S}), 785(\mathrm{C}-\mathrm{F}) ;{ }^{1} \mathrm{HNMR}(500 \mathrm{MHz}$, DMSO- $\left.d_{6}\right): \delta 11.92(\mathrm{~s}, 1 \mathrm{H}, \mathrm{NH}), 11.34(\mathrm{~s}, 1 \mathrm{H}, \mathrm{NH}), 8.75$ (s, 1H, H-2), 8.64 (s, 1H, H-6), $7.65(\mathrm{~s}, 1 \mathrm{H}, \mathrm{H}-4), 6.96-$ $6.92\left(\mathrm{~m}, 1 \mathrm{H}, \mathrm{H}-5^{\prime}\right), 6.35-6.30\left(\mathrm{~m}, 2 \mathrm{H}, \mathrm{H}-4^{\prime}, \mathrm{H}-6^{\prime}\right), 6.21$ (d, $\left.J=7.5 \mathrm{~Hz}, 1 \mathrm{H}, \mathrm{H}-1^{\prime}\right), 3.68$ (br. s, $\left.1 \mathrm{H}, \mathrm{OH}\right) ;{ }^{13} \mathrm{CNMR}$ $\left(125 \mathrm{MHz}, \mathrm{DMSO}-d_{6}\right)$ : $\delta 179.8(\mathrm{C}=\mathrm{S}), 169.4(\mathrm{C}=\mathrm{O})$, 163.1 (C3'), 140.3 (C2), 140.1 (C6), $138.6\left(\mathrm{C}^{\prime}\right), 134.1$ (C5), $130.5\left(\mathrm{C5}^{\prime}\right), 128.4$ (C3), 123.1 (C4), 122.0 (C6'), $115.4\left(\mathrm{C}^{\prime}\right)$, $111.3\left(\mathrm{C}^{\prime}\right)$; HR-MS for $\mathrm{C}_{13} \mathrm{H}_{10} \mathrm{FN}_{3} \mathrm{O}_{2} \mathrm{~S}$ calculated 291.0478 and found 291.0458; Anal. calcd. for $\mathrm{C}_{13} \mathrm{H}_{10} \mathrm{FN}_{3} \mathrm{O}_{2} \mathrm{~S}$ : C, 53.60; H, 3.46; N, 14.42; O, 10.98; S, 11.01; found: C, 53.59; H, 3.45 N, 14.41; O, 10.97; S, 11.01 .

\section{5-(3-(2-Bromophenyl) thioureido) pyridine-3-carboxylic acid} (12)

Yield: 71; M.p.: $>300^{\circ} \mathrm{C}$; FTIR (ATR, $\left.\mathrm{cm}^{-1}\right): 3333(\mathrm{~N}-\mathrm{H})$, $3191(\mathrm{Ar}-\mathrm{CH}), 1655(\mathrm{C}=\mathrm{O}), 1586(\mathrm{C}-\mathrm{N}), 1468(\mathrm{C}=\mathrm{C})$, 1331(C=S), 785(C-Br); ${ }^{1} \mathrm{HNMR}$ (500 MHz, DMSO- $d_{6}$ ): $\delta 11.72(\mathrm{~s}, 1 \mathrm{H}, \mathrm{NH}), 11.31$ (s, $1 \mathrm{H}, \mathrm{NH}), 8.70$ (s, 1H, H-2), $8.61(\mathrm{~s}, 1 \mathrm{H}, \mathrm{H}-6), 7.63(\mathrm{~s}, 1 \mathrm{H}, \mathrm{H}-4), 7.03(\mathrm{t}, J=7.0 \mathrm{~Hz}, 1 \mathrm{H}$, $\mathrm{H}-3)$, 6.98-6.95 (m, 1H, H-5), 6.45-6.40 (m, 2H, H-4, $\mathrm{H}-6), 3.64$ (br. s, $1 \mathrm{H}, \mathrm{OH}) ;{ }^{13} \mathrm{CNMR}(125 \mathrm{MHz}$, DMSO$\left.d_{6}\right): \delta 179.5(\mathrm{C}=\mathrm{S}), 169.3(\mathrm{C}=\mathrm{O}), 140.3(\mathrm{C} 2), 140.1(\mathrm{C} 6)$, 137.4 (C1'), 134.3 (C5), $132.2\left(\mathrm{C} 3^{\prime}\right), 128.9$ (C3), 128.6 (C6'), 128.0 (C5'), $127.4\left(\mathrm{C}^{\prime}\right)$, $127.1\left(\mathrm{C}^{\prime}\right)$ ), $123.4(\mathrm{C} 4)$; HR-MS for $\mathrm{C}_{13} \mathrm{H}_{10} \mathrm{BrN}_{3} \mathrm{O}_{2} \mathrm{~S}$ calculated 350.9677 and found 350.9677; Anal. calcd. for $\mathrm{C}_{13} \mathrm{H}_{11} \mathrm{~N}_{3} \mathrm{O}_{2} \mathrm{~S}$ : C, 44.33; $\mathrm{H}, 2.86$; N, 11.93; O, 9.09; S, 9.10; found: C, 44.31; H, 2.85; $\mathrm{N}, 11.91 ; \mathrm{O}, 9.07 ; \mathrm{S}, 9.09$.

\section{5-(3-(3-Bromophenyl) thioureido) pyridine-3-carboxylic acid}

(13)

Yield: 73\%; M.p.: $>300{ }^{\circ} \mathrm{C}$; FTIR (ATR, $\mathrm{cm}^{-1}$ ): 3337 $(\mathrm{N}-\mathrm{H}), 3191(\mathrm{Ar}-\mathrm{CH}), 1655(\mathrm{C}=\mathrm{O}), 1586(\mathrm{C}-\mathrm{N})$, 1468 $(\mathrm{C}=\mathrm{C}), 1331(\mathrm{C}=\mathrm{S}), 785(\mathrm{C}-\mathrm{Br}) ;{ }^{1} \mathrm{HNMR}(500 \mathrm{MHz}$, DMSO- $\left.d_{6}\right): \delta 11.78(\mathrm{~s}, 1 \mathrm{H}, \mathrm{NH}), 11.30(\mathrm{~s}, 1 \mathrm{H}, \mathrm{NH})$, 8.72 (s, $1 \mathrm{H}, \mathrm{H}-2), 8.60$ (s, $1 \mathrm{H}, \mathrm{H}-6), 7.62$ (s, $1 \mathrm{H}, \mathrm{H}-4)$, 6.88-6.85 (m, 1H, H-5'), 6.76-6.73 (m, 1H, H-4'), 6.62 $\left(\mathrm{d}, J=2.0 \mathrm{~Hz}, 1 \mathrm{H}, \mathrm{H}-2^{\prime}\right), 6.42\left(\mathrm{t}, J=7.5 \mathrm{~Hz}, 1 \mathrm{H}, \mathrm{H}-6^{\prime}\right)$, 3.66 (br. s, $1 \mathrm{H}, \mathrm{OH}) ;{ }^{13} \mathrm{CNMR}$ (125 MHz, DMSO- $\left.d_{6}\right): \delta$
$179.5(\mathrm{C}=\mathrm{S}), 169.3(\mathrm{C}=\mathrm{O}), 140.3$ (C2), $140.1(\mathrm{C} 6), 139.4$ (C1'), 134.3 (C5), 131.2 (C5'), 128.9 (C3), 127.5 (C4'), 125.7 (C6'), $125.3\left(\mathrm{C}^{\prime}\right), 123.6\left(\mathrm{C}^{\prime}\right)$, 123.4 (C4); HR-MS for $\mathrm{C}_{13} \mathrm{H}_{10} \mathrm{BrN}_{3} \mathrm{O}_{2} \mathrm{~S}$ calculated 447.0927 and found 447.0911; Anal. calcd. for $\mathrm{C}_{13} \mathrm{H}_{10} \mathrm{BrN}_{3} \mathrm{O}_{2} \mathrm{~S}$ : C, 44.33; $\mathrm{H}$, 2.86; 11.93; O, 9.09; S, 9.10; found: $\mathrm{C}, 44.32 ; \mathrm{H}, 2.85$; N, 11.92; O, 9.08; S, 9.08.

\section{Abbreviations}

NMR: nuclear magnetic resonance spectroscopy; FTIR: Fourier-transform infrared spectroscopy; ATR: attenuated total reflection; HR-MS: high resolution mass spectrometry; TLC: thin layer chromatography; p-NPG: 4-nitrophenyl-a-D-glucopyranoside.

\section{Acknowledgements}

Authors would like to express their gratitude towards the Institute for Research and Medical Consultations (IRMC) at IAU for the laboratory facilities and support.

\section{Authors' contributions}

Conceptualization and supervision, MN; Interpretation of data, MN and MT; Methodology and Synthesis, MN and FA; Writing and editing, MN, FA, MT and MS; Data analysis and characterization, NU and AW; Biological studies, SC and FAA; Docking studies, MS and SS. All authors read and approved the final manuscript.

\section{Funding}

This research was funded by Deanship of Scientific Research (DSR), Imam Abdulrahman Bin Faisal University (IAU) (Project Number: 2018-178-DSR).

\section{Availability of data and materials}

The datasets used and/or analysed during the current study will be available from the corresponding author on reasonable request.

\section{Competing interests}

The authors declare that they have no competing interests.

\section{Author details}

${ }^{1}$ Department of Nano-Medicine Research, Institute for Research and Medical Consultations (IRMC), Imam Abdulrahman Bin Faisal University, P.O. Box 1982, Dammam 31441, Saudi Arabia. ${ }^{2}$ Department of Clinical Pharmacy, Institute for Research and Medical Consultations (IRMC), Imam Abdulrahman Bin Faisal University, P.O. Box 1982, Dammam 31441, Saudi Arabia. ${ }^{3}$ Deanship of Scientific Research, Imam Abdulrahman Bin Faisal University, P.O. Box 1982, Dammam 31441, Saudi Arabia. ${ }^{4}$ Chemistry Department, King Fahd University of Petroleum \& Minerals, Dhahran 31261, Saudi Arabia. ${ }^{5}$ School of Chemical Engineering, Monash University, Bandar Subway, 47500 Selangor Darul Ehsan, Malaysia. ${ }^{6}$ School of Business Administration, College of International Education, Zhejiang Gongshang University, Hangzhou, China. ${ }^{7}$ Department of Medicinal Chemistry and Pharmacognosy, College of Pharmacy, Qassim University, Buraidah 52571, Saudi Arabia.

Received: 27 February 2020 Accepted: 7 July 2020 Published online: 14 July 2020

\section{References}

1. Global report on diabetes. @ World Health Organization (2016) https:// apps.who.int/iris/bitstream/handle/10665/204871/9789241565257_eng. pdf;jsessionid=AE86059D61D471EA76E470BD42579B18? sequence $=1$. Accessed 24 Nov 2019

2. Tiwari AK, Rao JM (2002) Diabetes mellitus and multiple therapeutic approaches of phytochemicals: present status and future prospects. Curr Sci 83:30-38 
3. Ghadyale V, Takalikar S, Haldavnekar V, Arvindekar A (2012) Effective control of postprandial glucose level through inhibition of intestinal alpha glucosidase by Cymbopogonmartinii (Roxb.). Evid Based Complement Alternat Med. https://doi.org/10.1155/2012/372909

4. Bedekar A, Shah K, Koffas M (2010) Natural products for type II diabetes treatment. In: Laskin Al, Sariaslani S, Gadd GM (eds) Advances in applied microbiology, vol 71. Elsevier Inc, California, pp 21-73

5. Tucci SA, Boyland EJ, Halford JCG (2010) The role of lipid and carbohydrate digestive enzyme inhibitors in the management of obesity: a review of current and emerging therapeutic agents. Diabetes Metab Syndr Obes 3:125-143. https://doi.org/10.2147/dmsott.s7005

6. Cai CY, Rao L, Rao Y, Guo XJ, Xiao ZZ, Cao JY, Huang ZS, Wang B (2017) Analoguesof xanthones-chalcones and bis-chalcones as a-glucosidase inhibitors and anti-diabetes candidates. Eur J Med Chem 130:51-59. https ://doi.org/10.1016/j.ejmech.2017.02.007

7. Mirza AZ, Arayne MS, Sultana N, Qureshi F (2013) Spectroscopic study to characterize in vitro interaction of losartan with gliquidone and pioglitazone. Med Chem Res 22(1):351-359. https://doi.org/10.1007/s0004 4-012-0036-8

8. Arayne MS, Sultana N, Haroon U, Qureshi F, Ali SA (2006) In vitro availability of atorvastatin in presence of losartan. Pak J Pharm Sci 19(2):134-141

9. Nawaz M, Arayne MS, Sultana N (2013) Drug interactions and synthesis of cefpirome with hypoglycemic agents. Med Chem Res 22(8):3581-3588. https://doi.org/10.1007/s00044-012-0365-7

10. Arayne MS, Sultana N, Qureshi F, Siddiqui FA, Mirza AZ, Bahadur SS, Zuberi MH (2009) Simultaneous determination of tranexamic acid and losartan potassium in dosage formulations and human serum by RP-LC. Chromatographia 70(5-6):789-795. https://doi.org/10.1365/s10337-009-1225-6

11. Rosa MM, Dias T (2014) Neurologic aspects of systemic disease part II. In: Biller J, Ferro JM (eds) Handbook of clinical neurology, vol 120. Elsevier, New York, pp 809-824

12. Gupta AK, Menon A, Brashear M, Johnson WD (2012) Prediabetesds: prevalence, pathogenesis, and recognition of enhanced risk. In: Bagchi D, Nair S (eds) Nutritional and therapeutic interventions for diabetes and metabolic syndrome. Elsevier Inc., New York, pp 57-75

13. Taha M, Shah SA, Imran S, Afifi M, Chigurupati S, Selvaraj M, Rahim F, Ullah H, Zaman K, Vijayabalan S (2017) Synthesis and in vitro study of benzofuranhydrazone derivatives as novel alpha-amylase inhibitor. Bioorg Chem 75:78-85. https://doi.org/10.1016/j.bioorg.2017.09.002

14. Slyusarenko El, Gorodetskova NP, Pesotskaya GV, Levchenko ES, Mogilevich SE, Do Luk'yanchuk V (1989) Pyridine derivatives possessing hypoglycemic and analgesic activity. Pharm Chem J 23:739. https://doi. org/10.1007/BF00764439

15. Nawaz M, Abbasi MW, Hisaindee S, Zaki MJ, Abbas HF, Mengting H, Ahmed MA (2016) Synthesis, spectral studies and biological evaluation of 2-aminonicotinic acid metal complexes. Spectrochim Acta A Mol Biomol Spectrosc 161:39-43. https://doi.org/10.1016/j.saa.2016.02.022

16. Nawaz M, Hisaindee S, Graham JP, Rauf MA, Saleh N (2013) Synthesis and Spectroscopic properties of Pyridones: experimental and theoretical insight. J Mol Liq 193:51-59. https://doi.org/10.1016/j.molliq.2013.12.033

17. Soylem EA, Assy MG, Morsi GM (2017) Michael cyclization of polarized systems: synthesis and in vitro anti-diabetic evaluation of some novel pyrimidine, pyridine, pyrazole and pyrazolo[3,4-b]pyridine derivatives. Croat Chem Acta 90(3):461-469. https://doi.org/10.5562/cca3122

18. Altaf AA, Shahzad A, Gul Z, Rasool N, Badshah A, Lal B, Khan E (2015) A review on the medicinal importance of pyridine derivatives. J Drug Des Med Chem 1(1):1-11. https://doi.org/10.11648/j.jddmc.20150101.11

19. Krause M, Foks H, Gobis K (2017) Pharmacological potential and synthetic approaches of imidazo[4,5-b]pyridineandimidazo[4,5-c]pyridine derivatives. Molecules 22(3):399. https://doi.org/10.3390/molecules22030399

20. Salar U, Khan KM, Chigurupati S, Taha M, Wadood A, Vijayabalan S, Ghufran M, Perveen S (2017) New hybrid hydrazinylthiazole substituted chromones: as potential a-amylase inhibitors and radical (DPPH \& ABTS) Scavengers. Sci Rep 7:16980. https://doi.org/10.1038/s41598-017-17261 -W

21. Salar U, Khan KM, Chigurupati S, Syed S, Vijayabalan S, Wadood A, Riaz M, Ghufran M, Perveen S (2019) New hybrid scaffolds based on hydrazinylthiazole substituted coumarin; as novel leads of dual potential; in vitro a-amylase inhibitory and antioxidant (DPPH and ABTS radical scavenging) activities. Med Chem 15(1):87-101. https://doi.org/10.2174/15734 06414666180903162243

22. Taha M, Baharudin MS, Ismail NH, Imran S, Khan MN, Rahim F, Selvaraj M, Chigurupati S, Nawaz M, Qureshi F, Vijayabalan S (2018) Synthesis, a-amylase inhibitory potential and molecular docking study of indole derivatives. Bioorg Chem 80:36-42. https://doi.org/10.1016/j.bioor g.2018.05.021

23. Imran S, Taha M, Selvaraj M, Ismail NH, Chigurupati S, Mohammad JI (2017) Synthesis and biological evaluation of indole derivatives as $\alpha$-amylase inhibitor. Bioorg Chem 73:121-127. https://doi. org/10.1016/j.bioorg.2017.06.007

24. Khan KM, Gollapalli M, Taha M, Hayat U, Nawaz M, AlMuqarrabun LMR, Rahim F, Qureshi F, Mosaddik A, Ahmat N (2018) Synthesis of Bisindolylmethanesulfonohydrazides derivatives as potent a-Glucosidase inhibitors. Bioorg Chem 80:112-120. https://doi.org/10.1016/j.bioor g.2018.06.001

25. Williams LK, Zhang X, Caner S, Tysoe C, Nguyen NT, Wicki J, Williams DE, Coleman J, McNeill JH, Yuen V, Andersen RJ, Withers SG, Brayer GD (2015) The amylase inhibitor montbretin A reveals a new glycosidase inhibition. Nat Chem Biol 11:691-696. https://doi.org/10.1038/nchembio.1865

26. Ren LM, Qin XH, Cao XF, Wang LL, Bai F, Bai G, Shen Y (2011) Structural insight into substrate specificity of human intestinal maltase-glucoamylase. Protein Cell 2:827-836. https://doi.org/10.1007/s13238-011-1105-3

27. Wu G, Robertson DH, Brooksill CL, Vieth M (2003) Detailed analysis of grid-based molecular docking: a case study of CDOCKER - a CHARMmBased MD Docking Algorithm. J Comp Chem 24:1549-1564. https://doi. org/10.1002/jcc.10306

\section{Publisher's Note}

Springer Nature remains neutral with regard to jurisdictional claims in published maps and institutional affiliations.

Ready to submit your research? Choose BMC and benefit from

- fast, convenient online submission

- thorough peer review by experienced researchers in your field

- rapid publication on acceptance

- support for research data, including large and complex data types

- gold Open Access which fosters wider collaboration and increased citations

- maximum visibility for your research: over $100 \mathrm{M}$ website views per year

At BMC, research is always in progress.

Learn more biomedcentral.com/submissions 